\title{
Low density lipoprotein
} receptor (LDLR) gene and ocular manifestation in Malay patients with familial hypercholesterolaemia

Nor Idahriani Muhd Nor ${ }^{1}$, Alyaa R. Al-Khateeb², Wan Hazabbah Wan Hitam¹, Zilfalil Bin Alwi ${ }^{3}$, Liza Sharmini Ahmad Tajudin ${ }^{1}$

${ }^{1}$ Department of Ophthalmology, School of Medical Sciences, Universiti Sains Malaysia, Kelantan, Malaysia; ${ }^{2}$ Human Genome Centre, School of Medical Sciences, Universiti Sains Malaysia, Kelantan, Malaysia; ${ }^{3}$ Department of Paediatrics, School of Medical Sciences, Universiti Sains Malaysia, Kelantan, Malaysia

\section{Abstract}

Introduction: Corneal arcus and eyelid xanthelasma are the common ocular findings but not exclusively found in familial hypercholesterolaemia (FH) patients. Low density lipoprotein receptor $(L D L R)$ gene is the one of the most common genes investigated in $\mathrm{FH}$. There is no study predicting ocular manifestations with genetic variations of the $L D L R$ gene.

Purpose: To associate common ocular manifestations of $\mathrm{FH}$ and $L D L R$ gene in Malays.

Material and methods: A cross-sectional study involving 50 unrelated Malay patients with FH were recruited. FH was diagnosed based on Dutch Lipid Clinic Network diagnostic criteria. The right eye was examined for eyelid xanthelasma and corneal arcus, while mean retinal nerve fibre layer thickness (RNFL) was assessed using Heidelberg retinal tomography II. Venepuncture was performed and genomic deoxyribonucleotide acid (DNA) was extracted. LDLR gene variations were screened using denaturing high-performance liquid chromatography and confirmed through DNA sequencing.

Correspondence: Dr. Liza Sharmini Ahmad Tajudin, School of Medical Sciences, Universiti Sains Malaysia, Health Campus, 16150 Kota Bharu, Kelantan, Malaysia.

E-mail: liza@usm.my; sharminiliz@live.com 
Results: Corneal arcus was detected in $86.0 \%$ of patients, while eyelid xanthelasma was detected in $2.0 \%$ of patients. Mean RNFL thickness was $254.16 \mu \mathrm{m}$ (SD: $60.67 \mu \mathrm{m}$ ). $L D L R$ gene variations were identified in 32 patients (64.0\%), including 5 mutations and 9 single nucleotide polymorphisms (SNPS). Two novel mutations were detected: c. $1705+117 \mathrm{~T}>\mathrm{G}$ and p.Asp139His. There was significant association between genotype frequency of $L D L R$ variations c.940+36G >A, p.Glu201Lys and p.Asp304Asn with FH, p.Glu201Lys with corneal arcus, and p.Cys255Ser and c.1705+117T>G with mean RNFL thickness.

Conclusion: $L D L R$ gene variations were not uncommon in Malay patients with $\mathrm{FH}$. Two novel variations, c.1705+117T >G and p.Asp139His, were identified. LDLR gene is a potential predictor genetic marker for corneal arcus in Malay patients with $\mathrm{FH}$. c. $1705+117 \mathrm{~T}>\mathrm{G}$ is associated with thinner mean RNFL thickness.

Keywords: corneal arcus, familial hypercholesterolaemia (FH), low density lipoprotein receptor $(L D L R)$ gene, retinal nerve fibre layer (RNFL) thickness

\section{Gen Reseptor lipoprotein berkepadatan rendah (LDLR) dan manifestasi okular dalam pesakit Melayu yang mengalami hiperkolesterolemia warisan}

\section{Abstrak}

Pengenalan: Arkus kornea dan xanthelasma kelopak mata adalah penemuan okular biasa tetapi tidak semata-mata dijumpai dalam pesakit hyperkolesterolaemia warisan (FH). Gen reseptor lipoprotein berkepadatan rendah $(L D L R)$ adalah salah satu daripada gen yang paling sering biasa disiasat dalam FH. Tiada sebarang kajian yang dibuat bagi meramalkan hubungkait variasi genetik gen LDLR dan manifestasi okular.

Tujuan: Untuk mengaitkan manifestasi okular umum dengan mutasi gen FH dan LDLR dalam pesakit FH berbangsa Melayu.

Bahan dan kaedah: Kajian rentas keratan yang melibatkan 50 orang pesakit Melayu yang tiada pertalian keluarga dan mengalami FH telah dijalankan. FH didiagnos berdasarkan kriteria diagnostik Dutch Lipid Clinic Network. Mata kanan diperiksa untuk xanthelasma kelopak mata dan arkus kornea, sementara ketebalan lapisan ketebalan serat saraf retina (RNFL) dinilai menggunakan Heidelberg retinal tomography II. Pengambilan darah vena telah dilakukan dan asid deoxyribonucleotide genomik (DNA) telah diekstrak. Variasi gen $L D L R$ ditapis 
menggunakan kromatografi cecair prestasi tinggi dan disahkan melalui penjujukan DNA.

Keputusan: Arkus kornea dikesan pada $86.0 \%$ pesakit, manakala xanthelasma kelopak dikesan pada $2.0 \%$ pesakit. Ketebalan purata RNFL adalah $254.16 \mu \mathrm{m}$ (SD: $60.67 \mu \mathrm{m})$. Variasi gen $L D L R$ telah dikenalpasti dalam 32 pesakit $(64.0 \%)$, termasuk 5 mutasi gen 9 tunggal polimorphisma nukleotida tunggal (SNP). Dua mutasi novel dikesan: c.1705+117T $>$ G dan p.Asp139His. Terdapat hubungan yang signifikan antara kekerapan genotip variasi $L D L R$ c.940+36G >A, p.Glu201Lys dan p.Asp304Asn dengan FH, p.Glu201Lys dengan arkus kornea, dan p.Cys255Ser dan c. $1705+117 \mathrm{~T}>\mathrm{G}$ dengan min purata ketebalan RNFL.

Kesimpulan: Variasi gen LDLR bukanlah tidak lazim dikalangan pesakit $\mathrm{FH}$ berbangsa Melayu. Malah dua variasi novel, c.1705+117T $>$ G dan p.Asp139His, telah dikenalpasti. Gen $L D L R$ adalah penanda genetik yang berpotensi sebagai peramal pembentukkan arkus kornea dikalangan pesakit Melayu dengan $\mathrm{FH}$. c. $1705+117 \mathrm{~T}>\mathrm{G}$ dikaitkan dengan kenipisan purata RNFL.

Kata kunci: arkus kornea, hyperkolesterolaemia warisan (FH), Gen reseptor lipoprotein ketumpatan rendah ( $L D L R)$, ketebalan lapisan serat saraf retina (RNFL)

\section{Introduction}

Familial hypercholesterolaemia (FH), an autosomal dominant disease, is considered a global public health problem due to elevated risk of premature coronary heart disease. ${ }^{1} \mathrm{FH}$ is characterized by elevated serum cholesterol. ${ }^{2} \mathrm{~A}$ majority of cases are caused by mutations in the low density lipoprotein receptor gene (LDLR). Other identified potential causative genes include apolipoprotein B100 and a protease known as proprotein convertase subtilin/kexin type 9 (PCSK9). ${ }^{3,4}$

The $L D L R$ gene is located on chromosome 19p13.1-13.3, spanning $45 \mathrm{~kb}$, and contains mature protein of 839 amino acids encoded by 18 exons and 17 introns. ${ }^{5}$ It is comprised of six functional domains: the signal sequence (exon 1); ligand binding domain (exon 2 to 6); epidermal growth factor precursor-like domain (exon 7 to 14); O-linked sugar domain (exon 15); transmembrane domain (exon 16 and some of 17); and the cytoplasmic domain (exon 18 and the rest of 17$).{ }^{5}$ It has been estimated around ten million people suffer from the disease worldwide. ${ }^{6}$ The homozygous type is very rare, affecting only 1 in 1,000,000 of the general population. ${ }^{6}$ Phenotypically, this type is characterized by accelerated atherosclerosis at early childhood and early development of coronary heart disease (CHD). ${ }^{4}$ The heterozygous type is the most common genetic disorder in Europe and United States, affecting 1 in 500 of the population. ${ }^{7}$ Heterozygous type is phenotypically less severe and CHD developed at a later age. ${ }^{8}$

Excess cholesterol leads to deposition of cholesterol in various tissue of the 
body including the eye. Eyelid xanthelasma is the most common type of cutaneous xanthoma. However, $25 \%$ to $70 \%$ of patients with eyelid xanthelasma have been found to have normal levels of cholesterol. ${ }^{9}$ The pathogenesis of corneal arcus is not fully understood, but has been postulated to share similarities with the atherosclerotic process. ${ }^{10}$ Hypercholesterolaemia has been implicated in the presence of corneal arcus in subjects less than 60 years old. ${ }^{11}$ In addition to the anterior segment manifestation, a reduction in the density of the retinal ganglion cells and thickness of the inner nuclear layer and photoreceptors has also been reported in hypercholesterolaemic-induced rabbits. ${ }^{12}$

To date, there have been genetic studies conducted on FH patients in Malaysia. ${ }^{13-15}$ However, there is no report on the association of ocular manifestation and genetic variations in Malay patients. Our aim in this study was to screen the $L D L R$ gene in Malay FH patients. The potential association between common ocular manifestations such as eyelid xanthelasthma, corneal arcus, and retinal nerve fibre layer (RNFL) thickness with LDLR gene was also studied.

Table 1. Dutch Lipid Clinic Network diagnostic criteria ${ }^{16}$

\begin{tabular}{|l|l|}
\hline Criteria & Points \\
\hline Family history & \multicolumn{2}{|l|}{} \\
\hline $\begin{array}{l}\text { First degree relative with known premature (men:<55 years; women:<60 years) } \\
\text { coronary and vascular disease or }\end{array}$ & 1 \\
\hline First degree relative with known LDL-c above 95 ${ }^{\text {th }}$ percentile & \\
\hline First degree relative with with tendinous xanthomata and or arcus cornealis or & \\
\hline Children aged less than 18 years with LDL-c above the 95 ${ }^{\text {th }}$ percentile & 2 \\
\hline Clinical history & \multicolumn{2}{|l|}{} \\
\hline Patient with premature (men:<55 years; women:<60 years) CHD & 2 \\
\hline $\begin{array}{l}\text { Patient with premature (men: }<55 \text { years; women: }<60 \text { years) cerebral or } \\
\text { peripheral vascular disease }\end{array}$ & 1 \\
\hline Physical examination & \multicolumn{2}{|l|}{} \\
\hline Tendinous xanthomata & 6 \\
\hline Arcus cornealis prior to age 45 years & 4 \\
\hline Cholesterol levels (mmol/L) & \multicolumn{2}{|l|}{} \\
\hline LDL-c $\geq 8.5$ & 8 \\
\hline LDL-c 6.5-8.4 & 5 \\
\hline LDL-c 5.0-6.4 & 3 \\
\hline LDL-c 4.0-4.9 & 1 \\
\hline DNA analysis & 8 \\
\hline Functional mutation in the LDLR gene & \multicolumn{2}{|l|}{} \\
\hline
\end{tabular}




\section{Methods}

\section{Patient recruitment and ocular examination}

A cross-sectional study was conducted involving 50 Malay patients with $\mathrm{FH}$ seen in the physician clinic, Hospital Universiti Sains Malaysia between June 2011 and April 2012. This study received ethical approval from Research and Ethical Committee, School of Medical Sciences, Universiti Sains Malaysia and was conducted in accordance to Declaration of Helsinki for human research.

Sample size calculation was based on two proportion formula and the expected sample size was 70 . However, due to time, financial constraints, and difficulty to find patients with $\mathrm{FH}$ who fulfilled the inclusion criteria, only 50 Malay patients were recruited. Diagnosis of FH was based on the Dutch Lipid Network diagnostic criteria (Table 1$).{ }^{16}$ According to the criteria, the recruited patients were divided into definite, probable, and possible $\mathrm{FH}$ based on the cumulative score. A pedigree chart was drawn for each patient to establish the diagnosis and to exclude potential mixed parentage or any uncertainty. The Malay ethnicity is defined as a person who professes to be a Muslim, habitually speaks the Malay language, and adheres to Malay custom, based on the Malaysian Constitution of $1964 .{ }^{17}$ Patients with CHD, history of acute myocardial infarction, percutaneous transluminal coronary angioplasty, and coronary artery bypass surgery were included. Exclusion criteria include secondary hypercholestrolaemia due to diabetes mellitus, hypothyroidism, renal disease, liver disease, and drugs taken (e.g., prednisolone). Those with preexisting ocular disease such as retinopathy or optic neuropathy were also excluded. Written consent was obtained after thorough explanation was given to the patients and family members.

A thorough ocular examination was conducted for both eyes, including external eye examination to identify eyelid xanthelasma. However, for the purpose of analysis, only the right eye was included. Corneal arcus was identified using a slit lamp biomicroscope (Topcon, Japan) with magnification (X10). For the purpose of grading corneal arcus, the peripheral cornea was divided into four quadrants: upper, lower, nasal, and temporal. The grading of severity of corneal arcus was based on the scoring system proposed by Varnek et al. on the densest corneal arcus chosen from one of the four quadrants. ${ }^{18}$ Corneal arcus grading was conducted by the primary investigator (NIMN).

Heidelberg Retinal Tomography (HRT) II (Heidelberg Engineering, Germany) was used to evaluate the structural changes of the optic nerve head. The pupil was dilated if the quality of image was poor due to a small pupil. An experienced masked technician was responsible in evaluating the optic nerve head. Mean RNFL thickness was obtained for statistical analysis. Fundus was also examined for any significant retinal change secondary to $\mathrm{FH}$, such as changes in vasculature or signs of ischaemia. 


\section{Screening of LDLR gene}

Venesection was conducted and $3 \mathrm{ml}$ of blood was collected in ethylenediaminetetraacetic acid (EDTA)-containing bottle for genetic analysis. DNA was extracted from the leukocytes using the standard procedure for commercial DNA extraction kit (QIAamp DNA extraction kit, QIAGEN, Germany). A total of 15 primers were designed to cover 18 exons and the promoter region of the LDLR gene. The primers were designed from reference sequences (accession no. NT_011295) (Table2) obtained from the Genebank of the National Centre of Biotechnology Information (NCBI) (http://www.ncbi.nlm.nih.gov/Genbank). The primers that covered the promoter region were selected based on previous study (Table 2). ${ }^{19}$ Polymerase chain reaction (PCR) was carried out. The PCR products were then run through the denaturing high performance lipid chromatography (dHPLC) to detect the presence of mutation or polymorphism in each amplified exon and promoter of the $L D L R$ gene. DNA sequencing was performed on samples with heteroduplexity to determine the specific type of mutations or polymorphisms.

\section{Statistical analysis}

Statistical Package for Social Sciences (SPSS) Windows version 19 (2010) was used for analysis. One-way ANOVA was used to determine the association between age, total cholesterol, LDL cholesterol, and mean RNFL thickness with FH diagnostic grouping. Association of genotype frequency of $L D L R$ variations with the ocular manifestation of $\mathrm{FH}$ was determined using a Fischer exact test. Independent t-test was used to analyse the mean RNFL thickness and $L D L R$ variation. $\mathrm{P}<0.05$ was deemed statistically significant.

\section{Results}

A total of 50 Malay patients with FH were recruited with a mean age of 46.2 (14.4) years. Male and female FH patients were equally distributed. Nearly half (46\%) fulfilled the criteria for possible FH based on the WHO definition. More than half (54\%) were hypertensive and $46 \%$ already developed ischemic heart disease (IHD) or myocardial infarction (MI). Eyelid xanthelasma was identified in only one patient (2\%). The most common ocular manifestation in $\mathrm{FH}$ patients was corneal arcus $(86 \%)$. Based on the severity of corneal arcus, $39.5 \%$ were mild, $37.2 \%$ moderate, and $23.3 \%$ severe. There were no significant retinal findings.

As expected, serum total cholesterol and LDL was highest in the definite $\mathrm{FH}$ group (Table 3). There was no significant difference in the presence of corneal arcus and mean RNFL thickness according to the definition of FH. However, there was a higher percentage of severe corneal arcus and thinner mean RNFL in definite FH compared to other groups (Table 3). 
Table 2. Primer sequence in LDLR

\begin{tabular}{|l|l|}
\hline Primer name & Primer sequence \\
\hline Promoter region $\mathrm{F}$ & 5'CAGCTCTTCACCGGAGACCC'3 \\
\hline Promoter region R & 5'ACCTGCTGTGTCCTAGCTGG'3 \\
\hline Exon 2 F & 5'CTGATTCTGGCGTTGAGAG'3 \\
\hline Exon 2 R & 5'GAGGCCAGCGGATCACTT'3 \\
\hline Exon 3 F & 5'GAGTGACAGTTCAATCCCTG'3 \\
\hline Exon 3 R & 5'GAAGAGGCTTGGTATGAGC'3 \\
\hline Exon 4 F & 5'GAGACTTCACACGGTGATG'3 \\
\hline Exon 4 R & 5'CCCAGGGACAGGTGATAG'3 \\
\hline Exon 5 F & 5'TCTGGTTGTCTCTTCTTGAG'3 \\
\hline Exon 5 R & 5'TGCAAGCAGCAAGGCACA'3 \\
\hline Exon 6 F & 5'TCAGACACACCTGACCTTC'3 \\
\hline Exon 6 R & 5'CCGTGCGAGACTGTCTCA'3 \\
\hline Exon 7 F & 5'GTTGTAATGAGCCAAGGTTG'3 \\
\hline Exon 7 R & 5'CTCCTAACTGCTTTCAAGCA'3 \\
\hline Exon 8 F & 5'TCTCCTGGCTGCCTTCGAA'3 \\
\hline Exon 8 R & 5'CTAGGACATATGCAGGCATC'3 \\
\hline Exon 9 F & 5'CACTCTTGGTTCCATCGAC'3 \\
\hline Exon 10 R & 5'CCACTAACCAGTTCCTGAA'3 \\
\hline Exon 11 F & 5'CTTCCAGAATTCGTTGCAC'3 \\
\hline Exon 11 R & 5'ACAGACCAAGACCTCATCT'3 \\
\hline Exon 12 F & 5'GTTCAGGCTCACATGTGGTT'3 \\
\hline Exon 12 R & 5'GTTCATCTTGGCTTGAGTG'3 \\
\hline Exon 15 F & 5'GTGAGAGAAGGTCAGCAAGG'3 \\
\hline Exon 15 R & \\
\hline
\end{tabular}

F: forward primer; R: reverse primer 
Table 3. Comparison of demographic, lipid profile, and ocular manifestation according to FH groups

\begin{tabular}{|c|c|c|c|c|}
\hline \multicolumn{5}{|c|}{ FH (WHO classification) } \\
\hline Criteria & $\begin{array}{l}\text { Definite } \\
\mathrm{N}=12\end{array}$ & $\begin{array}{l}\text { Probable } \\
\mathrm{N}=15\end{array}$ & $\begin{array}{l}\text { Possible } \\
N=23\end{array}$ & 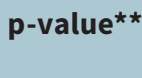 \\
\hline Age (year)* & $42.6(16.4)$ & $48.1(13.8)$ & 46.9 (13.9) & $0.590 a$ \\
\hline $\begin{array}{l}\text { Sex; } \mathrm{n}(\%) \\
\text { Male } \\
\text { Female }\end{array}$ & $\begin{array}{l}6(24.0) \\
6(24.0)\end{array}$ & $\begin{array}{l}11(44.0) \\
4(16.0)\end{array}$ & $\begin{array}{l}8(32.0) \\
15(60.0)\end{array}$ & $0.067 b$ \\
\hline Total cholesterol $(\mathrm{mmol} / \mathrm{L})^{\star}$ & $7.87(0.60)$ & $6.28(0.30)$ & $6.23(0.27)$ & $0.008 a$ \\
\hline $\mathrm{LDL}-\mathrm{c}(\mathrm{mmol} / \mathrm{L})^{\star}$ & $5.85(0.55)$ & $4.13(0.32)$ & $4.02(0.27)$ & $0.002 a$ \\
\hline Corneal arcus n (\%) & $9(20.9)$ & $14(32.5)$ & $20(46.5)$ & $0.388 \mathrm{c}$ \\
\hline $\begin{array}{l}\text { Severity of corneal arcus } n(\%) \\
\text { Mild } \\
\text { Moderate } \\
\text { Severe }\end{array}$ & $\begin{array}{l}1(5.8) \\
3(18.7) \\
5(50.0)\end{array}$ & $\begin{array}{l}5(29.4) \\
6(37.5) \\
3(30.0)\end{array}$ & $\begin{array}{l}11(64.7) \\
7(43.7) \\
2(20.0)\end{array}$ & $0.082 c$ \\
\hline Mean RNFL thickness $(\mu \mathrm{m})^{\star}$ & $\begin{array}{l}246.83 \\
(65.91)\end{array}$ & $\begin{array}{l}256.13 \\
(53.54)\end{array}$ & $\begin{array}{l}256.70 \\
(64.52)\end{array}$ & $0.895 a$ \\
\hline
\end{tabular}

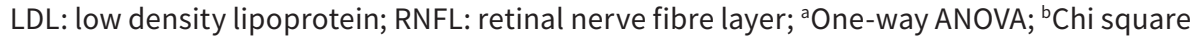
test; ' ${ }^{\circ}$ isher's exact test; ${ }^{\star}$ Mean (SD); ${ }^{* \star} p<0.05$ : statistically significant

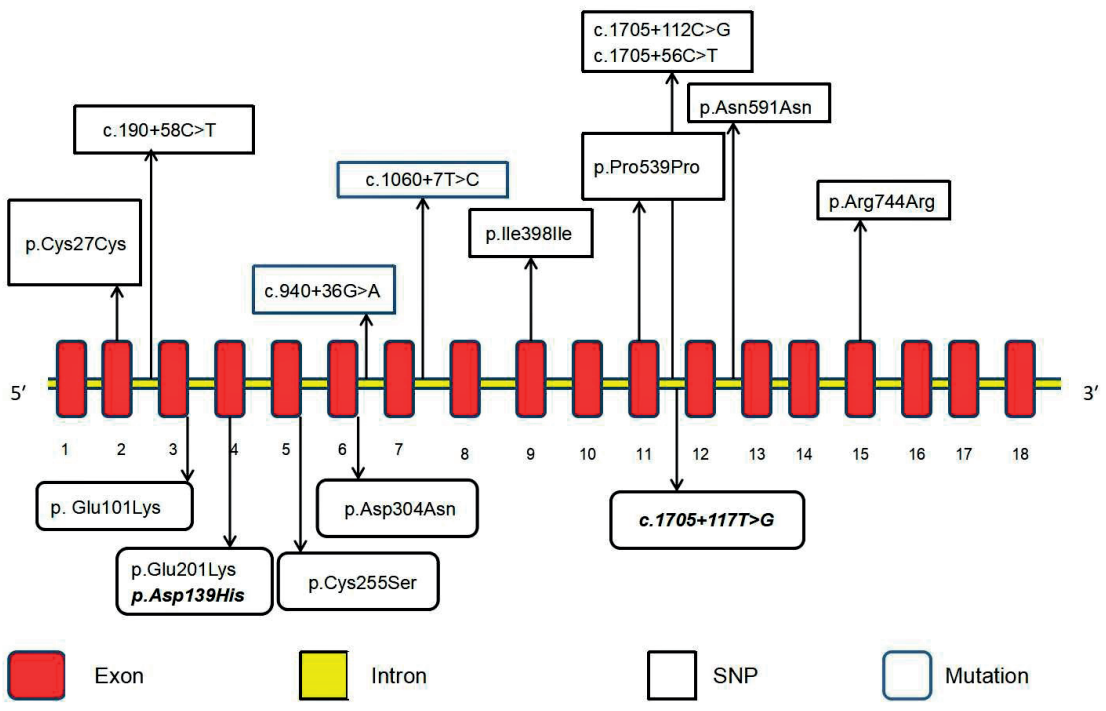

Fig. 1. Identification of LDLR gene variations in Malay patients with FH 
$L D L R$ gene variations were detected in 32 patients (64.0\%). Eighteen patients had no $L D L R$ gene variations. A total of 14 variants of the $L D L R$ gene were identified in Malay patients with $\mathrm{FH}: 5$ mutations and 9 single nucleotide polymorphisms (SNPs), including 2 novel mutations, Asp139His in exon 4 and 1705+117T>G in intron 11 (Fig. 1). The mutation type was mainly missense mutations except for one intronic mutation. There were 5 SNPs found in the exon and 4 in the intron (Fig. 1). Asp304Asn was found only in the probable group (Table 4). SNP 940+36GA was exclusively found in the probable group. Glu201Lys increased the possibility of manifestation of corneal arcus $(p=0.016)$ (Table 5$)$. However, there was no significant association with the severity of corneal arcus (Table 5). Mean RNFL thickness was significantly thinner in FH patients with Cys255Ser $(p=0.044)$ and 1705+117TG $(p=0.020)($ Table 5).

\section{Discussion}

Extensive study involving $\mathrm{FH}$ patients has been conducted worldwide. Malaysia is a multiracial country compromised of Malays (65\%), Chinese (26\%), and Indians (8\%). There have been several studies conducted in Malaysia involving the main ethnic groups. ${ }^{13,14}$ Our study was conducted exclusively among Malays diagnosed with $\mathrm{FH}$. In addition, to the best of our knowledge, this is the only available data on ocular manifestation of FH in Malays.

Xanthomatous deposition on the skin and tendon is the hallmark of homozygous $\mathrm{FH}$, but may not be found in heterozygous $\mathrm{FH}^{7,8}$ Deposition in the eye is not mandatory for diagnosis of $\mathrm{FH}$. Corneal arcus (86\%) is the most common ocular manifestation in Malays with $\mathrm{FH}$. Our percentage was much higher than reported in Hong Kong (63.5\%), Philippines (36.7\%), and Finland (16\%). ${ }^{20-22}$ In fact, it was higher than previously reported in Malaysia involving all major ethnic groups (31.8\%). ${ }^{14}$ Higher detection of corneal arcus in the current study may be due to more thorough ocular examination using slit lamp biomicroscopy examination. Detection of corneal arcus was essentially based on torchlight examination in previous studies, a process which may easily miss mild and early arcus..$^{20-22}$ However, there was no significant association between the severity of corneal arcus and the definition group of $\mathrm{FH}$. Nevertheless, due to a small sample size, our study was still unable to provide a conclusive association between severity of corneal arcus and FH. The small sample size in this study may also contribute to the low detection of xanthelasma.

Previous studies only concentrated on detection of xanthelasma in $\mathrm{FH}$, neglecting the ocular findings of the posterior segment. ${ }^{20-22}$ It has been postulated that atherosclerosis diminishes RNFL perfusion, causing acceleration of RNFL damage and reduction of RNFL thickness. This postulation was proven in an animal experimental study. ${ }^{12}$ Since $\mathrm{FH}$ may cause premature atherosclerosis, it may also affect ocular blood perfusion, particularly to the RNFL. ${ }^{10,11}$ Our study was unable to prove this postulation due to the absence of a control group (healthy individuals without 
Table 4. Genotype frequency of mutation and SNP found in $L D L R$ gene according to FH groups

\begin{tabular}{|c|c|c|c|c|c|}
\hline \multirow{2}{*}{ Variant sequence } & \multicolumn{4}{|c|}{ FH Groups n (\%) } & \multirow{2}{*}{ p-value } \\
\hline & & Definite & Probable & Possible & \\
\hline \multicolumn{6}{|l|}{ Mutation } \\
\hline \multirow[t]{2}{*}{ p.Glu201Lys } & GG & $9(20.0)$ & $13(28.9)$ & $23(51.1)$ & $0.029^{a}$ \\
\hline & GA & $3(60.0)$ & $2(40.0)$ & $0(0.0)$ & \\
\hline \multirow[t]{2}{*}{ p.Asp304Asn } & GG & $12(26.1)$ & $11(23.9)$ & $23(50.0)$ & $0.008^{a}$ \\
\hline & GA & $0(0.0)$ & $4(100.0)$ & $0(0.0)$ & \\
\hline \multirow[t]{2}{*}{ p.Glu101Lys } & GG & $11(22.9)$ & $14(29.2)$ & $23(47.9)$ & $0.287^{\mathrm{a}}$ \\
\hline & GA & $1(50.0)$ & $1(50.0)$ & $0(0.0)$ & \\
\hline \multirow[t]{2}{*}{ p.Asp139His } & GG & $11(22.4)$ & $15(30.6)$ & $23(46.9)$ & $0.240^{a}$ \\
\hline & GC & $1(100.0)$ & $0(0.0)$ & $0(0.0)$ & \\
\hline \multirow[t]{2}{*}{ p.Cys255Ser } & TT & $10(20.8)$ & 15 (31.3) & $23(47.9)$ & $0.054^{\mathrm{a}}$ \\
\hline & TA & $2(100.0)$ & $0(0.0)$ & $0(0.0)$ & \\
\hline \multirow[t]{2}{*}{ c. $1705+117 \mathrm{~T}>\mathrm{G}$} & TT & $12(25.0)$ & $15(31.3)$ & $21(43.8)$ & $0.493^{a}$ \\
\hline & TG & $0(0.0)$ & $0(0.0)$ & $2(100.0)$ & \\
\hline \multicolumn{6}{|l|}{ SNPs } \\
\hline \multirow[t]{2}{*}{ c. $940+36 \mathrm{G}>\mathrm{A}$} & GG & $12(25.5)$ & $12(25.5)$ & $23(48.9)$ & $0.034^{a}$ \\
\hline & GA & $0(0.0)$ & $3(100.0)$ & $0(0.0)$ & \\
\hline \multirow[t]{2}{*}{ c. $190+58 \mathrm{C}>\mathrm{T}$} & $\mathrm{CC}$ & $11(22.9)$ & $15(31.3)$ & $22(45.8)$ & $0.718^{\mathrm{a}}$ \\
\hline & $\mathrm{CT}$ & $1(50.0)$ & $0(0.0)$ & $1(50.0)$ & \\
\hline \multirow[t]{2}{*}{ p.Cys27Cys } & $\mathrm{CC}$ & $12(24.5)$ & $15(30.6)$ & $22(44.9)$ & $1.000^{\mathrm{a}}$ \\
\hline & $\mathrm{CT}$ & $0(0.0)$ & $0(0.0)$ & $1(100.0)$ & \\
\hline \multirow[t]{2}{*}{ p.lle398I1e } & $\mathrm{CC}$ & $12(24.5)$ & $14(28.6)$ & $23(46.9)$ & $0.540^{\mathrm{a}}$ \\
\hline & $\mathrm{CT}$ & $0(0.0)$ & $1(0.0)$ & $0(0.0)$ & \\
\hline \multirow[t]{2}{*}{ c. $1060+7 \mathrm{~T}>\mathrm{C}$} & TT & $12(24.5)$ & $14(28.6)$ & $23(46.9)$ & $0.540^{\mathrm{a}}$ \\
\hline & $\mathrm{TC}$ & $0(0.0)$ & $1(100.0)$ & $0(0.0)$ & \\
\hline \multirow[t]{2}{*}{ p.Pro539Pro } & $\mathrm{CC}$ & $12(24.5)$ & 15 (30.6) & $22(44.9)$ & $1.000^{\mathrm{a}}$ \\
\hline & $\mathrm{CT}$ & $0(0.0)$ & $0(0.0)$ & $1(100.0)$ & \\
\hline \multirow[t]{2}{*}{ c. $1705+56 C>T$} & $\mathrm{CC}$ & 11 (22.4) & 15 (30.6) & $23(46.9)$ & $0.240^{a}$ \\
\hline & $\mathrm{CT}$ & $1(100.0)$ & $0(0.0)$ & $0(0.0)$ & \\
\hline \multirow[t]{2}{*}{ C. $1705+112 C>G$} & $\mathrm{CC}$ & 12 (24.5) & 15 (30.6) & 22 (44.9) & $1.000^{\mathrm{a}}$ \\
\hline & CG & $0(0.0)$ & $0(0.0)$ & $1(100.0)$ & \\
\hline
\end{tabular}




\begin{tabular}{|l|l|l|l|l|l|}
\hline \multirow{2}{*}{ Variant sequence } & \multicolumn{4}{|c|}{ FH Groups n (\%) } & \multirow{2}{*}{ p-value* } \\
\cline { 2 - 6 } & & Definite & Probable & Possible & \\
\hline p.Asn591Asn & CC & $12(26.1)$ & $14(30.4)$ & $20(43.5)$ & $0.676^{\text {a }}$ \\
\hline & CT & $0(0.0)$ & $1(25.0)$ & $3(75.0)$ & \\
\hline p.Arg744Arg & AA & $11(22.9)$ & $15(31.2)$ & $22(45.8)$ & $0.718^{\text {a }}$ \\
\hline & AG & $1(50.0)$ & $0(0.0)$ & $1(50.0)$ & \\
\hline
\end{tabular}

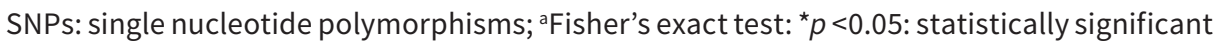

Table 5. Genotype frequency of mutation found in $L D L R$ gene according to corneal arcus, severity of corneal arcus, and mean RNFL thickness

\begin{tabular}{|c|c|c|c|c|}
\hline \multirow[b]{2}{*}{ Variant sequence } & \multirow[b]{2}{*}{ Genotype } & \multicolumn{2}{|c|}{ Corneal arcus } & \multirow[b]{2}{*}{ p-value* } \\
\hline & & $\begin{array}{l}\text { Present } \\
\mathrm{N}=43\end{array}$ & $\begin{array}{l}\text { Absent } \\
N=7\end{array}$ & \\
\hline \multicolumn{5}{|l|}{ Mutation } \\
\hline \multirow[t]{2}{*}{ p.Glu201Lys } & GG & $41(91.0)$ & $4(8.9)$ & $0.016^{a}$ \\
\hline & GA & $2(40.0)$ & $3(60.0)$ & \\
\hline \multirow[t]{2}{*}{ p.Glu101Lys } & GG & 41 (85.4) & $7(14.6)$ & $0.737^{\mathrm{a}}$ \\
\hline & GA & $2(100.0)$ & $0(0.0)$ & \\
\hline \multirow[t]{2}{*}{ p.Asp139His } & GG & $42(85.7)$ & $7(14.3)$ & $0.860^{\mathrm{a}}$ \\
\hline & $\mathrm{GC}$ & $1(100.0)$ & $0(0.0)$ & \\
\hline \multirow[t]{2}{*}{ p.Cys255Ser } & TT & $41(85.4)$ & $7(14.6)$ & $0.737^{\mathrm{a}}$ \\
\hline & TA & $2(100.0)$ & $0(0.0)$ & \\
\hline \multirow[t]{2}{*}{ p.Asp304Asn } & GG & $40(87.0)$ & $6(13.0)$ & $0.464^{\mathrm{a}}$ \\
\hline & GA & $3(75.0)$ & $1(25.0)$ & \\
\hline \multirow[t]{2}{*}{$c .1705+117 \mathrm{~T}>\mathrm{G}$} & TT & $42(87.5)$ & $6(12.5)$ & $0.263^{\mathrm{a}}$ \\
\hline & TG & $1(50.0)$ & $1(50.0)$ & \\
\hline
\end{tabular}




\begin{tabular}{|c|c|c|c|c|c|}
\hline \multirow{2}{*}{$\begin{array}{l}\text { Variant } \\
\text { sequence }\end{array}$} & \multirow{2}{*}{ Genotype } & \multicolumn{3}{|c|}{ Severity of corneal arcus } & \multirow{2}{*}{ p-value* } \\
\hline & & Mild & Moderate & Severe & \\
\hline \multirow[t]{2}{*}{ p.Glu101Lys } & GG & $16(39.0)$ & $16(39.0)$ & $9(22.0)$ & $0.699^{a}$ \\
\hline & GA & $1(50.0)$ & $0(0.0)$ & $1(50.0)$ & \\
\hline \multirow[t]{2}{*}{ p.Asp139His } & GG & $17(40.5)$ & $16(38.1)$ & $9(21.4)$ & $0.233^{\mathrm{a}}$ \\
\hline & GC & $0(0.0)$ & $0(0.0)$ & $1(100.0)$ & \\
\hline \multirow[t]{2}{*}{ p.Glu201Lys } & GG & $16(39.0)$ & $15(36.6)$ & $10(24.4)$ & $1.000^{\mathrm{a}}$ \\
\hline & GA & $1(50.0)$ & $1(50.0)$ & $0(0.0)$ & \\
\hline \multirow[t]{2}{*}{ p.Asp304Asn } & GG & $16(40.0)$ & $15(37.5)$ & $9(22.5)$ & $1.000^{\mathrm{a}}$ \\
\hline & GA & $1(33.3)$ & $1(33.3)$ & $1(33.3)$ & \\
\hline \multirow[t]{2}{*}{ p.Cys255Ser } & TT & $17(41.5)$ & $15(36.6)$ & $9(22.0)$ & $0.511^{\mathrm{a}}$ \\
\hline & TA & $0(0.0)$ & $2(100.0)$ & $0(0.0)$ & \\
\hline \multirow[t]{2}{*}{ c. $1705+117 \mathrm{~T}>\mathrm{G}$} & $\mathrm{TT}$ & $17(40.5)$ & $15(35.7)$ & $10(23.8)$ & $0.605^{a}$ \\
\hline & TG & $0(0.0)$ & $1(100.0)$ & $0(0.0)$ & \\
\hline $\begin{array}{l}\text { Variant } \\
\text { sequence }\end{array}$ & Genotype & \multicolumn{3}{|c|}{$\begin{array}{l}\text { RNFL thickness } \\
\text { Mean (SD) ( } \mu \mathrm{M})\end{array}$} & p-value* \\
\hline \multirow[t]{2}{*}{ p.Cys255Ser } & $\mathrm{TT}$ & \multicolumn{3}{|c|}{$257.67(59.04)$} & $0.044 b$ \\
\hline & TA & \multicolumn{3}{|c|}{$170.00(42.43)$} & \\
\hline \multirow[t]{2}{*}{ c. $1705+117 \mathrm{~T}>\mathrm{G}$} & TT & \multicolumn{3}{|c|}{$254.98(61.80)$} & $0.020^{b}$ \\
\hline & TG & \multicolumn{3}{|c|}{$234.50(7.78)$} & \\
\hline \multirow[t]{2}{*}{ p.Glu101Lys } & GG & \multicolumn{3}{|c|}{$256.08(61.18)$} & $0.277^{\mathrm{b}}$ \\
\hline & GA & \multicolumn{3}{|c|}{$208.00(2.83)$} & \\
\hline \multirow[t]{2}{*}{ p.Asp139His } & GG & \multicolumn{3}{|c|}{$253.82(61.25)$} & $0.782^{\mathrm{b}}$ \\
\hline & $\mathrm{GC}$ & \multicolumn{3}{|c|}{$271.00(0.00)$} & \\
\hline \multirow[t]{2}{*}{ p.Glu201Lys } & GG & \multicolumn{3}{|c|}{$257.33(62.30)$} & $0.272^{\mathrm{b}}$ \\
\hline & GA & \multicolumn{3}{|c|}{$225.60(35.60)$} & \\
\hline \multirow[t]{2}{*}{ p.Asp304Asn } & GG & \multicolumn{3}{|c|}{$251.46(60.55)$} & $0.290^{\mathrm{b}}$ \\
\hline & GA & \multicolumn{3}{|c|}{$285.25(61.08)$} & \\
\hline
\end{tabular}

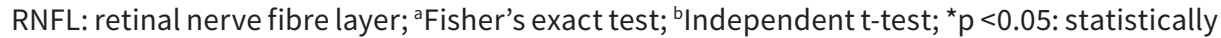
significant 
$\mathrm{FH})$. There was no significant difference in mean RNFL thickness according to the recommended definition group of $\mathrm{FH}$. The thinnest mean RNFL thickness was observed in the definite FH group.

$L D L R$ gene variations were detected in more than half of our Malay patients with $\mathrm{FH}(64 \%)$. The mutation rate of the $L D L R$ gene in our study was higher compared to previous studies in Malaysia (26.7\%), the Philippines (20.0\%), and Taiwan (9.2\%). . $^{14,21,23}$ Mexicans with $\mathrm{FH}$ had a higher rate of mutation (37.0\%). ${ }^{24}$ The rate of SNP in our study was higher than in Taiwan (6.9\%). ${ }^{23}$ The different rate of $L D L R$ gene variation might be due to the different diagnostic criteria used for $\mathrm{FH}$ and the sensitivity and specificity of the methods used for the detection of $L D L R$ gene variation. ${ }^{25,26}$ For example, Khoo et al. used denaturing gradient gel electrophoresis (DGGE) for $L D L R$ gene mutation screening. ${ }^{14}$ DHPLC was reported to be superior to DGGE. ${ }^{27}$

Missense mutations were the most common mutation. The most common types of $L D L R$ gene mutation in this study occurred in exon 4 (6 patients). Glu201Lys was detected in five patients and Asp139His in one patient. As reported in the University College London LDLR database, exon 3 and 4 were the so-called 'hot-spot' for $L D L R$ variations. ${ }^{28}$ The second most common mutation was Asp304Asn in exon 6 (4 patients). A similar mutation was reported in one $\mathrm{FH}$ patient in France. ${ }^{29}$

Two novel mutations, Asp139His in exon 4 (accession no: HM853677) and $1705+117 T>G$ in intron 11 (accession no: HQ190924), were identified in our Malay patients with $\mathrm{FH}$. The missense mutation of Asp139His occurred due to substitution of $\mathrm{G}$ to $\mathrm{C}$ at nucleotide 415 , causing the change of aspartate acid to histidine located at 3 rd cysteine-rich repeat of ligand binding domain. ${ }^{30} \mathrm{~A}$ change in the amino acid affects the binding of LDL cholesterol to the receptor. ${ }^{28}$ Intronic mutation of c. $1705+117 \mathrm{~T}>\mathrm{G}$ in intron 11 is another novel mutation. There was limited knowledge on intronic mutation causing disease. ${ }^{29}$ Perhaps intronic mutation increases the susceptibility to develop FH.

Apart from the mutation, nine SNPs were also identified in our FH patients. There was a significant difference in genotype frequency of Glu201Lys, Asp304Asn, and $940+36 \mathrm{G}>\mathrm{A}$ according to the definition of $\mathrm{FH}$. Heterozygous of these mutations and SNP seem to be found exclusively in probable FH patients. Glu201Lys was also found in definite $\mathrm{FH}$ patients. $L D L R$ is the potential marker for $\mathrm{FH}$ in Malays. However, $L D L R$ variation was not detected in $34 \%$ of our recruited patients. Other genes may be responsible in these patients.

To the best our knowledge, this is the first report on the association of $L D L R$ with ocular manifestations in FH patients. Glu201Glu was found to associate with corneal arcus. Glu201Lys was only found in two patients with corneal arcus. Regression of corneal arcus has not yet been reported in humans. Corneal arcus may represent a phenotype marker for exposure to dyslipoprotenaemia and reflex the tissue deposition with atheroma. ${ }^{31} L D L R$ gene variation has potential as the predictor for ocular manifestation of $\mathrm{FH}$. However, there was no association between $L D L R$ variations and corneal arcus severity. There is a possibility of ethnic- or popula- 
tion-specific mutation. ${ }^{30} \mathrm{~A}$ larger sample size is needed to conclude this association. There was no significant association of the identified SNPs with corneal arcus.

Asn591Asn was detected in one patient with bilateral xanthelasma who also presented with tendon xanthoma but without history of $\mathrm{CHD}$. It was previously reported that xanthelasma increased the risk of CHD. ${ }^{23}$ Reduction of RNFL thickness was seen in hypercholesterolaemic induced animals due to the enhanced activity of nitric oxide synthase that lead to retinal ganglion cell apoptosis. ${ }^{13}$ Thinner mean RNFL thickness was found in patients with the novel intronic mutation $1705+117 \mathrm{~T}>\mathrm{G}$. However, $1705+117$ TG was found in only two patients. Thus, thinner mean RNFL perhaps occurs by chance and not really in relation to the mutation. For a similar reason, significantly thinner RNFL thickness was also observed in patients with Cys255Ser.

The major weakness of this study is the small sample size, especially for achieving conclusive findings on the association between the $L D L R$ gene and $\mathrm{FH}$. The sample size seems to be adequate for genotype association with corneal arcus. Nevertheless, this study provides baseline data for future studies. Identification of potential genetic markers in $\mathrm{FH}$ is important in the prevention of mortality and morbidity related complications.

\section{Acknowledgements}

We thank the patients who participated in this study. This study was financially supported by eScience Fund grant No. 305/PPSP/6113212, Ministry of Science, Technology and Innovation (MOSTI), Malaysia.

\section{References}

1. Marks D, Thorogood M, Neil HAW, Humphries SE. A review on the diagnosis, natural history, and treatment of familial hypercholesterolaemia. Atherosclerosis. 2003;168(1):1-14.

2. Yang KC, Su YN, Shew JY, et al. LDLR and ApoB are major genetic causes of autosomal dominant hypercholesterolemia in a taiwanese population. J Formos Med Assoc. 2007; 106(10):799-807.

3. Datta BN, Cole DS, Shortland GJ. Hyperlipidaemia. Paediatr Child Health. 2010;21(2):94-98.

4. Farnier M, Bruckert E. Severe familial hypercholesterolaemia: Current and future management. Arch Cardiovasc Dis. 2012; 105(12):656-665.

5. Sudhof T, Goldstein JL, Brown MS, Russell DW. The LDL receptor gene: a mosaic of exons shared with different proteins. Science. 1985;228(4701):815.

6. Fernando C. Guidelines for the diagnosis and management of heterozygous familial hypercholesterolemia. Atherosclerosis. 2004;173(1):55-68.

7. David S. Guidelines for the diagnosis and management of familial hypercholesterolaemia. Heart Lung Circ. 2007;16(1):25-27. 
8. Graham CA, McClean E, Ward AJM, et al. Mutation screening and genotype:phenotype correlation in familial hypercholesterolaemia. Atherosclerosis. 1999;147(2):309-316.

9. Bergman R. The pathogenesis and clinical significance of xanthelasma palpebrarum. J Am Acad Dermatol. 1994;30(2, Part 1):236-242.

10. Fernandez AB, Keyes MJ, Pencina M, D’Agostino R, O’Donnell CJ, Thompson PD. Relation of corneal arcus to cardiovascular disease (from the Framingham Heart Study Data Set). Am J Cardiol. 2009;103(1):64-66.

11. Hoogerbrugge N, Happee C, van Domburg R, Poldermans D, van den Brand M JBM. Corneal arcus: indicator for severity of coronary atherosclerosis? Neth J Med. 1999;55(4):184-187.

12. Shibata M, Sugiyama T, Hoshiga M, et al. Changes in optic nerve head blood flow, visual function, and retinal histology in hypercholesterolemic rabbits. Exp Eye Res. 2011;93(6):818-824.

13. Junit SM, Othman S, Yusof R, Billett MA, Harun F. Ala519Thr Mutation in Exon 11 of LDL Receptor Gene in Members of a Malaysian Family with Hypercholesterolaemia. As Pac J Mol Biol Biotechnol. 2003;11(2):77-82.

14. Khoo K, Van Acker P, Tan H, Deslypere J. Genetic causes of familial hypercholesterolaemia in a Malaysian population. Med J Malaysia. 2000;55(4):409-418.

15. Livy A. Lye SH. Familial hypercholesterolemia in Asia: A Review. OMICS Res. 2011;1(1):22-31.

16. World Health Organization. Familial hypercholesterolaemia (FH): report of a second WHO consultation, Geneva, 4 September 1998, World Health Organization, Geneva. http://whqlib.who.int/ hq/1999/WHO_HGN_FH_CONS_99.2.pdf.

17. Groves HE. The Constitution of Malaysia 1964. Malaysia Publications.

18. Varnek L, Schnohr P, Jensen G. Presenile corneal arcus in healthy persons. A possible cardiovascular risk indicator in younger adults. Acta Ophthalmol. 1979; 57(5):755-65.

19. Bodamer OA, Bercovich D, Schlabach M, Ballantyne C, Zoch D, Beaudet AL. Use of denaturing HPLC to provide efficient detection of mutations causing familial hypercholesterolemia. Clin Chem. 2002; 48(11):1913-1918.

20. Hu M, Lan W, Lam CW, Mak YT, Pang CP, Tomlinson B. Heterozygous familial hypercholesterolemia in Hong Kong Chinese. Study of 252 cases. Int J Cardiol. 2013;167(3):762-767.

21. Punzalan FER, Sy RG, Santos RS, Cutiongco EM, et al. Low density lipoprotein-receptor (LDL-R) gene mutations among Filipinos with familial hypercholesterolemia. J Atheroscler Thromb. 2005;12(5):276.

22. Koivisto P, Koivisto U-M, Miettinen TA, Kontula K. Diagnosis of heterozygous familial hypercholesterolemia. DNA analysis complements clinical examination and analysis of serum lipid levels. Arterioscler Thromb Vasc Biol. 1992;12(5):584-592.

23. Yang KC, Su YN, Shew JY, et al. LDLR and ApoB are major genetic causes of autosomal dominant hypercholesterolemia in a Taiwanese population. J Formos Med Assoc. 2007;106 (10):799-807.

24. Robles-Osorio L, Huerta-Zepeda A, Ordoez ML, et al. Genetic heterogeneity of autosomal dominant hypercholesterolemia in Mexico. Arch Med Res. 2006;37(1):102-108.

25. Austin MA, Hutter CM, Zimmern RL, Humphries SE. Genetic causes of monogenic heterozygous familial hypercholesterolemia: a HuGE prevalence review. Am J Epidemiol. 2004;160(5):407-420.

26. Watts GF, Sullivan DR, Poplawski N, van Bockxmeer F, et al. Familial hypercholesterolaemia: A model of care for Australasia. Atheroscler Suppl. 2011;12(2):221-263. 
27. Meldrum CJ, McPhillips M, Crooks R, et al. A comparison between denaturing gradient gel electrophoresis and denaturing high performance liquid chromatography in detecting mutations in genes associated with hereditary non-polyposis colorectal cancer (HNPCC) and the identifications of 9 new mutations previously unidentified by DGGE. Hered Cancer Clin Pract. 2003;1(1):39-48.

28. Leigh, S, Foster A, Whittall R, Hubbart C, Humphries S. Update and analysis of the University College London low density lipoprotein receptor familial hypercholesterolemia database. Ann Hum Genet. 2008; 72(4):485-498.

29. Amsellem S, Briffaut D, Carrie A, et al. Intronic mutations outside of Alu-repeat-rich domains of the LDL receptor gene are a cause of familial hypercholesterolemia. Hum Genet. 2002;111(6): 501-510.

30. Russell DW, Brown MS, Goldstein JL. Different combinations of cysteine-rich repeats mediate binding of low density lipoprotein receptor to two different proteins. J Biol Chem. 1989; 264(36): 21682-21688.

31. Winder AF. Corneal arcus \& prognosis in familial hypercholesterolaemia (FH). Atherosclerosis 1987; 68(3):276. 